\section{Turfgrass Performance of Diploid Buffalograss [Buchloe dactyloides (Nutt.) Engelm.] Half-sib Populations}

\author{
Desalegn D. Serba \\ Forage Improvement Division, The Samuel Roberts Noble Foundation, Inc., \\ Ardmore, OK 73401
}

Osman Gulsen

Department of Horticulture, Faculty of Agriculture, Erciyes University, Melikgazi, 38039 Kayseri, Turkey

Bekele G. Abeyo
CIMMYT, ILRI Campus, Addis Ababa, Ethiopia

Keenan L. Amundsen ${ }^{1}$, Donald J. Lee, and P. Stephen Baenziger

Department of Agronomy and Horticulture, University of Nebraska-Lincoln, 377H Plant Science Hall, Lincoln, NE 68583

Tiffany M. Heng-Moss

Department of Entomology, University of Nebraska-Lincoln, Lincoln, NE 68583

Kent M. Eskridge
Department of Statistics, University of Nebraska-Lincoln, Lincoln, NE 68583

Robert C. Shearman

Department of Agronomy and Horticulture, University of Nebraska-Lincoln, Lincoln, NE 68583

Additional index words. turfgrass, quality, lateral spread, spring density, genetic color

\begin{abstract}
Hybridization and selection has been one of the methods used to generate turfgrass cultivars in buffalograss improvement. Three half-sib populations were developed by crossing three buffalograss female genotypes, NE 3296, NE 2768, and NE 2769, with NE 2871, a male genotype, to 1) investigate the pattern of genetic variability generated for turfgrass characteristics through hybridization; 2) assess the effect of parental change on the level of genetic variability generated in a buffalograss diploid population; and 3) predict the performance of a progeny generated from two heterozygous parents for turfgrass performance. The four parents and 20 random $F_{1}$ progeny selected from each population were established in 2006 at the John Seaton Anderson Turfgrass Research Facility located near Mead, NE. A randomized complete block design (RCBD) was used with the progeny nested in the crosses. A visual rating scale of 1-9 was used to evaluate the population. Mean population lateral spread, genetic color, density, and turfgrass quality from early summer to fall ranged from 3.5 to 4.5, 7.1 to 7.9, 6.9 to 8.1 , and 5.2 and 6.8 , respectively. There were significant differences among the crosses and the parents for all the traits studied except quality in June and August. The progeny nested within crosses differed for turfgrass genetic color and quality. Best linear unbiased prediction (BLUP) indicated a high improvement potential for turfgrass lateral spread and spring density in NE $2768 \times$ NE 2871 and for turfgrass genetic color in NE $3296 \times$ NE 2871 . From these findings, it can be concluded that hybridization breeding is a worthwhile approach for generating and identifying transgressive segregants for specific buffalograss traits.
\end{abstract}

Buffalograss is a warm-season $\left(\mathrm{C}_{4}\right)$ grass species that originated in Central Mexico (Quinn and Engel, 1986; Quinn et al., 1994; Shaw et al., 1987; Webb, 1941). It is a fine-

Received for publication 15 Dec. 2011. Accepted for publication 6 Jan. 2012.

${ }^{1}$ To whom reprint requests should be addressed; e-mailkamundsen2@unl.edu. is highly variable with plants growing side by side differing in certain vegetative or reproductive characteristics (Wenger, 1949).

The genetic make-up of buffalograss is complex. It exists in several ploidy levels that are essentially alike phenotypically and indistinguishable from one another (Budak et al., 2004; Huff et al., 1993; Johnson et al., 2001; Reeder, 1971). The most prominent difference among ploidy levels is geographical adaptation (Shearman et al., 2004). The diploids are thought to be the original forms from which the upper ploidy levels evolved and are adapted to the southern regions of buffalograss-growing areas in North America. The tetraploids are southern and central-adapted, whereas the hexaploids are generally more widely adapted, but some, like ' 609 ', are more suited to the southern range of buffalograss adaptation (Huff et al., 1993; Johnson et al., 2001). A molecular study of buffalograss genotypes of different ploidy levels observed a linear increase in the number of alleles in the hexaploids as compared with tetraploids and diploids (Budak et al., 2005). This increased number of alleles is believed to have contributed to the broadbased adaptation of the hexaploids.

Early buffalograss improvement efforts emphasized on selection and hybridization mostly to develop forage types (Wenger, 1949). Germplasm collections were found to have extensive variability from which increased vigor, green color retention, taller seed stalks, and increased disease-resistant types could be selected (Beetle, 1950). However, the level of improvement that can be achieved through hybridization is not well known. Recently, results from a buffalograss pseudo-testcross progeny study for improved seed production in Nebraska indicated that seed yield could be increased up to 10 -fold by selective parental hybridization (Abeyo and Shearman, 2009). Organelle and nuclear analyses of buffalograsses with different ploidy series indicated that chloroplast and mitochondrial genomes are uniparental and variability was mainly the result of nuclear genome (Budak et al., 2005; Gulsen et al., 2005). Nevertheless, the potential amount of buffalograss improvement for turfgrass quality, pest resistance, and stress tolerance that may be achieved through hybridization has not been established.

It is essentially impossible to generate inbred buffalograss lines by self-fertilization because buffalograss is a self-incompatible, dioecious species (Brewbaker, 1957). Hence, the genotypes available for breeding are always heterozygous. The advantage of planned hybridization of heterozygous genotypes needs to be extensively studied for subsequent exploitation for the improvement of various traits in the breeding program.

This study was conducted to evaluate halfsib populations with the following objectives: 1) investigate the pattern of genetic variability generated for turfgrass characteristics through hybridization breeding; 2) assess if change in one parent has an effect on the level of genetic variability generated in a buffalograss diploid population; and 3) predict the performance of 
a progeny generated from two heterozygous parents for turfgrass performance.

\section{Materials and Methods}

Parental genotypes and generation of halfsibs. Three diploid female genotypes (NE 3296, NE 2768, and NE 2769) and one diploid male genotype (NE 2781) were selected for use in this study based on their sex expression, turfgrass quality, and chinch bug resistance. The three female genotypes were pollinated with the male to generate three half-sib populations. The crosses were made in isolation from other sources of buffalograss pollen in the greenhouse at University of NebraskaLincoln, East Campus in Lincoln, NE, that was maintained at $33{ }^{\circ} \mathrm{C}$ maximum and $16{ }^{\circ} \mathrm{C}$ minimum temperatures, $\pm 2{ }^{\circ} \mathrm{C}$, and a photoperiod of 15:9 h (light:dark) with supplemental light provided by Philips $400-\mathrm{W}$ metal halide bulbs (MH400/U; Day-Brite Lighting, Tupelo, MS).

The pots of the female and male parents were arranged next to each other on the bench for effective pollen transfer to the female inflorescences. The burs were hand-harvested from each female parent and then kept in a seed storage room at $40{ }^{\circ} \mathrm{C}$ and $40 \%$ relative humidity. The caryopses were removed from the burs using 1- to 2-s pulses of an electric coffee grinder (Krups GX4100 Coffee Grinder; Cookware Inc., Boston, MA) adapted from Riordan et al. (1997). The caryopses were germinated on trays filled with a soil mix of sand-soil-peat-perlite in 2:1:3:3 ratios $(\mathrm{v} / \mathrm{v})$ covered with a thin soil layer $(\approx 3.0 \mathrm{~mm})$ distributed over them. A seed establishment blanket (Master Gardner Co., Spartanburg, SC) was used as a mulch to cover the top of the tray to avoid the disturbance of the germinating seed while watering. The tray was hand-watered daily to keep the soil and the geminating seed moist.

When the seedlings reached the four- to five-leaf stage, they were transplanted to $15 \mathrm{~cm}$ diameter $\times 15 \mathrm{~cm}$ deep pots containing a $35 \%$ peat:32\% vermiculite: $9 \%$ soil: $24 \%$ sand $(\mathrm{v} / \mathrm{v})$ soil mixture. Soil was saturated every 2 weeks with nutrient solution $(21 \mathrm{~N}-3.5 \mathrm{P}-15 \mathrm{~K})$ containing $200 \mathrm{mg} \cdot \mathrm{L}^{-1}$ nitrogen, $35 \mathrm{mg} \cdot \mathrm{L}^{-1}$ phosphorus, and $150 \mathrm{mg} \cdot \mathrm{L}^{-1}$ potassium. The greenhouse was maintained at $25 \pm 1{ }^{\circ} \mathrm{C}$ with supplemental light supplied by Phillips 400-W metal halide lamps with a photoperiod of $15 / 9 \mathrm{~h}$ (light/dark). Stolons from the plants grown in the pots were cut into pieces containing one node each and planted in $5.0 \mathrm{~cm}$ depth $\times 5.0 \mathrm{~cm}$ width cells filled with the soil mix described previously.

Field establishment and management. The three half-sib populations represented each by 20 progeny and the four parents were planted in the field in May 2006 at the John Seaton Anderson Turfgrass Research Facility located near Mead, NE. Two-month-old, vegetative plugs of each progeny and the parental genotypes were planted in a Tomek silty-clay loam (fine smectitic mesic Pachic Agriudolls). Plugs were planted $60 \mathrm{~cm}$ apart. The experiment was laid out with three crosses and four parents as seven treatments in a RCBD with three replications. Twenty progeny were nested within a cross of parental genotypes, whereas 20 clones were nested within the parental plots.

A starter fertilizer $(18 \mathrm{~N}-20 \mathrm{P}-0 \mathrm{~K})$ was applied at $60 \mathrm{~kg}$ nitrogen $(\mathrm{N})$ per hectare at planting time. Post-establishment fertilizer was also applied at $60 \mathrm{~kg} \mathrm{~N}$ per hectare using sulfur-coated urea (46N-0P-0K) in July 2006 and in mid-June and mid-July in 2007. Irrigation was applied at $25 \mathrm{~mm}$ per month including rainfall. Oxadiazon [2-tert-butyl-4(2, 4 dichloro-5-isopropoxyphenyl)- $\Delta-1,3,4$ oxadiazolin-5-one] was applied at $3.14 \mathrm{~kg} /$ a.i./ha for pre-emergent weed control. Quinclorac (3, 7-dichloro-8-quinolinecarboxylic acid), was applied at $0.84 \mathrm{~kg} / \mathrm{a} . \mathrm{i} . / \mathrm{ha}$ to each treatment plot for post-emergent weed control. The plots were maintained at $5-\mathrm{cm}$ mowing height weekly and clippings were removed.

Data collection and analysis. In 2006, only lateral spread data were collected. Genetic color was recorded on 8 May 2007, density was evaluated early in the summer (3 July 2007), and turfgrass quality data were collected on 12 June, 14 Aug., and 16 Oct. 2007. A visual rating scale of 1-9 was used for all the traits considered with $1=$ light tan and $9=$ dark green, $1=0 \%$ to $10 \%$, and $9=80 \%$ to $100 \%$ stand density and $1=$ poorest, $5=$ acceptable, and $9=$ best for color, density, and quality, respectively.

Mixed model analysis (SAS Version 9.1; SAS Institute, Cary, NC) was used to detect differences among the half-sibs and their parents and to estimate the BLUPs (Henderson, 1975) for the progeny in full-sibs. In the mixed model analysis, the parents and the crosses were considered as fixed effects, whereas the progeny within the crosses was considered random, because they were randomly selected from a population of sibs as indicated in the model:

$$
\begin{aligned}
Y_{i j k}= & \mu+\mathrm{R}_{i}+A_{i}+\varepsilon_{i j} \\
& +B(A)_{k(i)}+\varepsilon_{i j k} .
\end{aligned}
$$

where $i$ designates the replications $(i=1-3), j$ designates the crosses and parents $(j=1-7)$, and $\mathrm{k}$ the progeny $(\mathrm{k}=1-20)$. Furthermore, $\mathrm{k}$ (i) indicates that progeny are nested within crosses.

To predict the prospect of identifying superior progeny by hybridizing two or more genotypes, the progeny population, both at full-sib and half-sib levels, needs to be evaluated. This step requires further analysis to predict if a cross will generate the intended variability for the traits of interest. Best linear unbiased prediction has been used in plant breeding for the estimation of random effects of a mixed model (Dutkowski et al., 2002; Piepho et al., 2008; White and Hodge, 1989; Xiang and Li, 2003). In this experiment, the parental crosses were considered as fixed and the progeny as random effects. The BLUP corresponds to the conditional expectation of the random effect given observation on the corresponding random factor in the experiment (Panter and Allen, 1995). This procedure enables the estimation of overall progeny performance from a cross by using a few random progeny and is a feasible method in predicting the significance of hybridization breeding.

\section{Results and Discussion}

There were highly significant $(P<0.01)$ differences among the crosses and the parents for all the traits studied except for quality evaluated in June and August (Table 1). The progeny nested within crosses differed only for turfgrass genetic color and turf quality observed in October. The significance for turfgrass quality in October indicated the genetic variability of the progeny for green color retention in the fall, which is an important characteristic for warm-season turfgrass.

The targets of selection in the breeding process are the transgressive progeny. Based on the direction of improvement sought for a particular trait, the target of selection can be either the lower or the upper extremes of the variability. Therefore, variability within the progeny of a full-sib family must be evaluated for improvement potential over the parental values. This circumstance requires further analysis to compare the progeny at the fullsib level and each with their parental means

Table 1. Analysis of variance of buffalograss half-sib populations and their parents for turfgrass lateral spread, genetic color, spring density, and quality at the John Seaton Anderson Turfgrass Research Facility located near Mead, NE, 2007.

\begin{tabular}{lrllllll}
\hline Source & df & $\begin{array}{c}\text { Lateral } \\
\text { spread }^{z}\end{array}$ & $\begin{array}{c}\text { Genetic } \\
\text { color }^{\mathrm{y}}\end{array}$ & $\begin{array}{c}\text { Spring } \\
\text { density }^{\mathrm{x}}\end{array}$ & $\begin{array}{c}\text { Quality }^{\mathrm{w}} \\
\text { (June) }\end{array}$ & $\begin{array}{c}\text { Quality } \\
\text { (August) }\end{array}$ & $\begin{array}{c}\text { Quality } \\
\text { (October) }\end{array}$ \\
\hline $\begin{array}{l}\text { Replication (R) } \\
4 \text { parents and 3 }\end{array}$ & 2 & 22.57 & 0.57 & 6.71 & 10.77 & 8.6 & 7.58 \\
$\quad$ crosses (C) & & $9.37^{*}$ & $5.51^{*}$ & $9.71^{*}$ & $2.99 \mathrm{NS}$ & $1.52 \mathrm{NS}$ & $5.53^{*}$ \\
$\mathrm{R} * \mathrm{C}$ (error a) & 12 & 3.10 & 1.16 & 2.95 & 1.89 & 1.02 & 1.67 \\
Progeny(cross) & 133 & $0.90 \mathrm{NS}$ & $0.18^{*}$ & $0.77 \mathrm{NS}$ & $0.64 \mathrm{NS}$ & $0.54 \mathrm{NS}$ & $0.65^{* *}$ \\
Error (b) & 266 & 0.86 & 0.14 & 0.84 & 0.56 & 0.46 & 0.40 \\
Total & 419 & & & & & &
\end{tabular}

${ }^{\mathrm{z}}$ Lateral spread is measure of lateral growth of genotypes as visually evaluated using a $1-9$ scale $(1=1$ east, $9=$ most)

${ }^{y}$ Genetic color is the measure of greenness of the genotypes as visually evaluated using a $1-9$ scale $(1=$ straw brown, 9 = dark green).

${ }^{\mathrm{x}}$ Spring density is the measure living plants or tillers per unit area of the genotypes visually evaluated using a $1-9$ scale $(1=$ least dense, 9 = most dense $)$.

${ }^{\text {w}}$ Quality is based on visual rating scale of $1-9$ with $1=$ poorest, $5=$ acceptable, and $9=$ best.

*Significant at $P=0.05$; ** significant at the $P=0.01$; ns $=$ nonsignificant. 
or the best parental value for each of the traits. It was evident that some progeny outperformed their parents for the traits considered, indicating the significance of hybridization and selection for improvement over the parental means.

The parental genotypes NE 2769 and NE 2768 had very competitive lateral spread. None of the progeny means was better than these two parental genotypes. The four parental genotypes NE 3296, NE 2768, NE2769, and NE2781 (male parent) had a mean genetic color scale of 7.1, 7.9, 7.9, and 7.3, respectively. Genetic color improvement was observed only for the NE $3296 \times$ NE 2781 cross (Table 2). Spring density is another important trait for warm-season turfgrasses, especially those growing in regions where they remain dormant from early fall through late spring. Improvement in spring density was observed for the progeny of the cross involving NE 3296 as the female parent (Table $2)$. This improvement was over the female and not the male parent. The three maternal genotypes, NE 3296, NE 2768, and NE 2769, had mean spring density ratings of 7.1, 7.3, and 7.4, respectively. To extend the appealing look of the turfgrass, early spring green-up and green color retention in the fall are two important characteristics sought in warmseason turfgrass improvement.

Turfgrass quality is one of the most difficult traits to measure quantitatively and the relative ratings are based on a combination of uniformity, color, density, texture, and growth habit (Beard, 1973). It also considers pests resistance and environmental stress tolerance. Thus, it takes into account aesthetic and functional aspects of the turfgrass (Morris and Shearman, 2009). In late spring or early summer, it was difficult to differentiate the quality performance of the parents and the crosses. In mid-June, NE 3296 had an average turfgrass quality rating 5.7, which was the lowest rating as compared with the quality performance of the other parental genotypes and progeny families (Table 2). In mid-August, only NE 2768 had an average quality rating of 6.8 , which was significantly higher than the quality performance of other parental genotypes and progeny families. Mid-October turfgrass quality ratings were reduced for all the genotypes and families with the range between 5.2 and 6.1 (Table 2). The maternal genotype, NE 2768 , had a high average quality rating of 6.1 . This result indicated variation for green color retention and growth among the genotypes. NE 2768 also showed consistent turfgrass quality performance over the growing season, and none of the progeny or other parental genotypes outperformed it.

The relative performance for other traits also needs consideration when selecting among genotypes or within progeny. The two parental genotypes, NE 2768 and NE 2769, that had the best lateral spread exhibited average genetic color and spring density. The mean turfgrass quality rating was highest (6.5) in August but reduced to 5.6 in October (Table 2). This reduction is because light quality and quantity and temperature reduction directly affect chlorophyll decomposition and regeneration of warm-season grasses in the fall. As a result, the warm-season grasses reduce their photosynthetic rates and drift into dormancy. In this study, only diploids were evaluated, which, as previously mentioned, are southern-adapted. Late in November, when most other higher ploidy-level buffalograsses were dormant at the research site, the diploids were still growing, and they experienced severe winter injury and had considerable stand loss by the next spring.

There were both positive and negative values indicating the importance of a particular progeny in relation to other progeny within a full-sib family (Fig. 1). The BLUP analysis is used to broaden the inference range to the $F_{1}$ segregating population from which to select a progeny of interest. From this random sample, an interpretation can be made for the entire population of a particular cross and predicts which cross combination can bring about a significant improvement for a trait or combination of traits.

Table 2. Mean separation of buffalograss half-sib populations and their parents for turfgrass genetic color, spring density and quality conducted at the John Seaton Anderson Turfgrass Research Facility, near Mead, NE, 2007.

\begin{tabular}{lllllll}
\hline Cross/parent & $\begin{array}{c}\text { Lateral } \\
\text { spread }^{\mathrm{z}}\end{array}$ & $\begin{array}{c}\text { Genetic } \\
\text { color }^{\mathrm{x}}\end{array}$ & $\begin{array}{c}\text { Spring } \\
\text { densityw }^{\mathrm{w}}\end{array}$ & $\begin{array}{c}\text { Quality }^{\mathrm{v}} \\
\text { (June) }^{2}\end{array}$ & $\begin{array}{c}\text { Quality } \\
\text { (August) }\end{array}$ & $\begin{array}{c}\text { Quality } \\
\text { (October) }\end{array}$ \\
NE 3296 & $3.8 \mathrm{~b}^{\mathrm{y}}$ & $7.1 \mathrm{e}$ & $7.1 \mathrm{bc}$ & $5.7 \mathrm{~cd}$ & $6.3 \mathrm{~b}$ & $5.6 \mathrm{~b}$ \\
NE 3296 $\times$ NE 2781 & $3.9 \mathrm{~b}$ & $7.5 \mathrm{c}$ & $8.1 \mathrm{a}$ & $6.4 \mathrm{a}$ & $6.5 \mathrm{ab}$ & $5.3 \mathrm{~cd}$ \\
NE 2768 & $4.5 \mathrm{a}$ & $7.9 \mathrm{a}$ & $7.3 \mathrm{~b}$ & $6.2 \mathrm{abc}$ & $6.8 \mathrm{a}$ & $6.1 \mathrm{a}$ \\
NE 2768 $\times$ NE 2781 & $3.9 \mathrm{~b}$ & $7.6 \mathrm{bc}$ & $6.9 \mathrm{c}$ & $5.9 \mathrm{~cd}$ & $6.5 \mathrm{ab}$ & $5.7 \mathrm{~b}$ \\
NE 2769 & $4.5 \mathrm{a}$ & $7.9 \mathrm{a}$ & $7.4 \mathrm{~b}$ & $6.1 \mathrm{bc}$ & $6.5 \mathrm{ab}$ & $5.5 \mathrm{bc}$ \\
NE 2769 $\times$ NE 2781 & $3.7 \mathrm{bc}$ & $7.7 \mathrm{~b}$ & $7.1 \mathrm{~b}$ & $6.1 \mathrm{bc}$ & $6.5 \mathrm{ab}$ & $5.3 \mathrm{~d}$ \\
NE 2781 (male) & $3.5 \mathrm{c}$ & $7.3 \mathrm{~d}$ & $7.8 \mathrm{a}$ & $6.3 \mathrm{ab}$ & $6.3 \mathrm{~b}$ & $5.2 \mathrm{~d}$ \\
\hline
\end{tabular}

${ }^{\mathrm{z}} \mathrm{A}$ visual rating scale of $1-9$ was used for all the traits considered with $1=$ light $\tan$ and $9=$ dark green, $1=$ $0 \%$ to $10 \%$ and $9=80 \%$ to $100 \%$ stand density, and $1=$ poorest, $5=$ acceptable, and $9=$ best for color, density and quality, respectively.

${ }^{y}$ Any two means within a column followed by the same letter are not significantly different from each other $(P \leq 0.05)$.

${ }^{x}$ Genetic color is the inherent color of the genotype based on a visual rating scale of $1-9$ with $1=$ straw brown and $9=$ dark green.

wDensity is a visual rating on a 1-9 scale of living plants or tillers per unit area with $1=$ least and $9=$ most. ${ }^{\vee}$ Quality is based on visual rating scale of $1-9$ with $1=$ poorest, $5=$ acceptable, and $9=$ best.

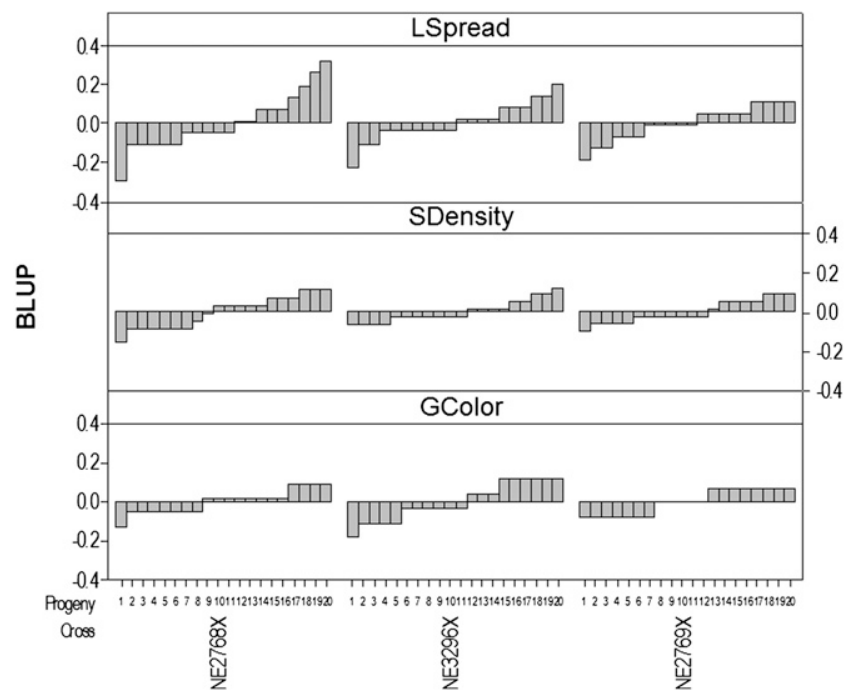

Fig. 1. Best linear unbiased predictor (BLUP) for turfgrass lateral spread (LSpread), spring density (SDensity), and genetic color (GColor) for 20 selected progeny from three half-sib populations of diploid buffalograss evaluated at Mead, NE, 2007. 
improved traits can be selected. As true for other plant breeding programs, careful parental selection is needed before crossing to generate sufficient genetic variability. Because most of the loci are heterozygous as a result of outcrossing characteristics of buffalograss, it is imperative to include parental genotypes that have diversity in their genetic make-up for the traits needing improvement. Based on the BLUP analysis for lateral spread, the NE $2768 \times$ NE 2781 cross gave the greatest level of variability and subsequently better potential improvement for establishment and sod-forming characteristics. This same cross is expected to bring about a significant improvement in spring density. For genetic color, the cross NE $3296 \times$ NE 2781 would be expected to make an improvement over the best parent. From the result of this investigation, it can be concluded that progenies generated from crossing two distinct heterozygous genotypes can generate a superior progeny. This breeding system enables buffalograss breeders to use the partial heterosis prevailing in such outcrossing species.

\section{Literature Cited}

Abeyo, B. and R.C. Shearman. 2009. Buffalograss (Buchloe dactyloides) turfgrass performance and seed yield characteristics. Intl. Turfgrass Soc. Res. J. 11:519-532.

Beard, J.B. 1973. Turfgrass science and culture. Prentice Hall, Englewood Cliffs, NJ.

Beetle, A.A. 1950. Buffalograss-native of the shortgrass plains. Agr. Expt. Sta., Univ. of WY, Laramie Bull 293:1-31.

Brewbaker, J.I. 1957. Pollen cytology and selfincompatibility systems in plants. J. Hered. 48:271-277.

Budak, H., R.C. Shearman, and I. Dweikat. 2005. Evolution of Buchloë dactyloides based on cloning and sequencing of matK, rbcL, and cob genes from plastid and mitochondrial genomes. Genome 48:411-416.

Budak, H., R.C. Shearman, I. Parmaksiz, R.E. Gaussoin, T.P. Riordan, and I. Dweikat. 2004. Molecular characterization of buffalograss germplasm using sequence-related amplified polymorphism markers. Theor. Appl. Genet. 108:328-334.

Chase, A. 1979. First book of grasses: The structure of grasses explained for beginners. Smithsonian Institution Press, Washington D.C.

Dutkowski, G.W., J. Costa e Silva, A.R. Gilmour, and G.A. Lopez. 2002. Spatial analysis methods for forest genetic trials. Can. J. Forest Res. 32:2201-2214.

Gulsen, O., R.C. Shearman, K.P. Vogel, D.J. Lee, and T. Heng-Moss. 2005. Organelle DNA diversity among buffalograsses from the great plains of North America determined by cpDNA and mtDNA RFLPs. Crop Sci. 45:186-192.

Henderson, C.R. 1975. Best linear unbiased estimation and prediction under a selection model. Biometrics 31:423-447.

Huff, D.R., R. Peakall, and P.E. Smouse. 1993. RAPD variation within and among natural populations of outcrossing buffalograss [Buchloë dactyloides (Nutt.) Engelm.]. Theor. Appl. Genet. 86:927-934.

Johnson, P.G., K.E. Kenworthy, D.L. Auld, and T.P. Riordan. 2001. Distribution of buffalograss polyploid variation in the southern great plains. Crop Sci. 41:909-913.

Morris, K.N. and R.C. Shearman. NTEP turfgrass evaluation guidelines [online]. 10 Sept. 2009. $<$ http://www.ntep.org $>$.

Panter, D.M. and F.L. Allen. 1995. Using best linear unbiased predictions to enhance breeding for yield in soybean: II. Selection of superior crosses from a limited number of yield trials. Crop Sci. 35:405-410.

Piepho, H.P., A.J. Mohring, A.E. Melchinger, and A. Buchse. 2008. BLUP for phenotypic selection in plant breeding and variety testing. Euphytica 161:209-228.
Quinn, J.A. and J.L. Engel. 1986. Life-history strategies and sex ratios for a cultivar and a wild population of Buchloe Dactyloides (Gramineae). Amer. J. Bot. 73:874-881.

Quinn, J.A., D.P. Mowrey, S.M. Emanuele, and R.D.B. Whalley. 1994. The 'foliage is the fruit' hypothesis: Buchloe dactyloides (Poaceae) and the Shortgrass Prairie of North America. Amer. J. Bot. 81:1545-1554.

Reeder, J. 1971. Notes on Mexican grasses. IX. Miscellaneous chromosome numbers - 3. Brittonia 23:105-117.

Riordan, T.P., S.A. de Shazer, J.M. Johnson-Cicalese, and R.C. Shearman. 1993. An overview of breeding and development of buffalograss. Intl. Turfgrass Soc. Res. J. 7:816-822.

Riordan, T.P., P.G. Johnson, R.E. Gaussoin, and J.F. Svoboda. 1997. Seedling germination and establishment of buffalograss caryopses vs. burs. Intl. Turfgrass Soc. Res. J. 8:749-756.

Shaw, R.B., C.M. Bern, and G.M. Winkler. 1987. Sex ratios of Buchloe dactyloides (Nutt.) Englem. along catenas on the short grass steppe. Bot. Gaz. 148:85-89.

Shearman, R.C., T.P. Riordan, and P.G. Johnson. 2004. Buffalograss, p. 1003-1026. In: Moser, L.E., B.L. Burson, and L.E. Sollenberger (eds.). Agronomy Monograph Vol. 45. Warm-season (C-4) grasses. American Society of Agronomy, Madison, WI.

Webb, J.J., Jr. 1941. The life history of buffalograss. Trans. Kans. Acad. Sci. 44:58-74.

Wenger, L.E. 1949. Buffalo grass. Bulletin 321. Kansas State College of Agriculture and Applied Science, Kansas Agricultural Experiment Station, Manhattan, KS.

White, T.L. and G.R. Hodge. 1989. Predicting breeding values with applications in forest tree improvement. Kluwer, Dordrecht, The Netherlands.

Xiang, B. and B.L. Li. 2003. Best linear unbiased prediction of clonal breeding values and genetic values from full-sib mating designs. Can. J. For. Res. 33:2036-2043. 